\title{
Ç2-Türkçe ve Fransızca yazışma metinlerinin çeviri yönünden incelenmesi
}

\section{Ziya TOK'}

APA: Tok, Z. (2019). Türkçe ve Fransızca yazışma metinlerinin çeviri yönünden incelenmesi. RumeliDE Dil ve Edebiyat Araştırmaları Dergisi, (16), 470-478. DOI: 10.2900o/rumelide.580711

\section{$\ddot{O} \mathbf{z}$}

Yazışma, bir dilin karşılıklı olarak yazılı bir biçimde kullanılması ve bu yolla iletişimin kurulması anlamına gelir. Yazıda kullanılan dil, sözlü dildeki kadar önemlidir. Sözlü dilin ve yazılı dilin kullanım alanları birbirinden farklılık gösterir ve belirli durum ya da ortamlarda sözlü dil yerine yazılı dilin kullanılması gerekebilir. Dilin amaçlarından biri kuşkusuz etkili bir iletişim kurmak olduğuna göre iletişimin sağlıklı bir biçimde sağlanabilmesinde yazılı dil oldukça önemli bir rol üstlenir. Her toplumda yazılı iletişime başvurma ve bu yöntemi kullanma amaçları yaklaşık olarak birbirine benzerdir. Örneğin hemen hemen bütün toplumlarda resmi bir başvuru işlemi yazllı bir biçimde yapılır. Bununla birlikte, yazışma metinlerinde kullanılan dil ve içerik bir toplumdan diğerine farklılıklar bazı içerebilir. Bu da yazışma metinlerinin bir dilden diğerine çevirisinde altı çizilmesi gereken önemli konulardan birini oluşturur. Bu çalışmada, Türkçede ve Fransızcada yazılı iletişimin türleri ve yazışma metinlerindeki dil kullanımı karşılaştırmalı bir biçimde ele alınacaktır. Daha sonra her iki dildeki gerek resmi gerekse samimi yazışma metinlerinde yer alan dilsel benzerlikler ve farklılıklar üzerinde durulacaktır. Bu bağlamda, Türkçe ve Fransızca resmi yazışma metinlerinden karşılaştırmalı örnek metinler ve bu metinlerin çevirileri incelenecektir. Bu örneklerden hareketle, bu iki dilde yazışma metinlerinin çevirisinde ortaya çıkabilecek güçlükler üzerinde durulacak ve bu güçlüklere yönelik olarak çözüm önerilerine yer verilecektir.

Anahtar kelimeler: Yazışma, yazı dili, yazışma metinleri, çeviri.

\section{Analyze of Turkish and French correspondence texts in terms of translation}

\begin{abstract}
Correspondence refers to the use of the language in a written way and communicating in this way. The language used in the text is as important as the oral language. The areas of use of oral language and written language differ from each other, and in certain situations or environments it may be necessary to use the written language instead of the oral language. As one of the aims of language is to establish an effective communication, written language plays an important role in ensuring communication in a healthy way. The objectives of applying and using written communication in each community are similar. For example, in almost all societies a formal application procedure is made in writing. However, the language and content used in correspondence texts may contain differences from one society to another. This is one of the important issues that should be underlined in the translation of correspondence texts from one language to another. In this study, the types of written communication in Turkish and French and the use of language in correspondence texts will be discussed in a comparative manner. Then, the linguistic similarities and differences in both official and intimate correspondence will be emphasized. In this context, comparative sample texts from
\end{abstract}

1 Dr. Öğretim Üyesi, Kırıkkale Üniversitesi, Fen-Edebiyat Fakültesi, Batı Dilleri Ve Edebiyatları Bölümü (Kırıkkale, Türkiye), ziya-tok@hotmail.com, ORCID ID: 00oo-0002-7686-9808 [Makale kayit tarihi: 16.06.2019-kabul tarihi: 20.09.2019; DOI: 10.29000/rumelide.580711] 
Turkish and French official correspondence and their translations will be examined. Based on these examples, the difficulties that may arise in the translation of the texts of correspondence in these two languages will be mentioned and suggestions for solutions to these difficulties will be included.

Keywords: Correspondence, written language, correspondence texts, translation.

\section{Dil ve iletişim}

Dil, insanlık tarihi boyunca bireylerin ve toplumların birbirleriyle iletişim kurabilmek için ihtiyaç duydukları en önemli gereksinimlerden biridir. Türk Dil Kurumu'nun sözlüğünde "İnsanlarn düşündüklerini ve duyduklarm bildirmek için kelimelerle veya işaretlerle yaptıkları anlaşma" (2011:664), biçiminde tanımlanan dil, insanlar arasındaki iletişimin en temel unsurudur. İletişim ise, bir gönderici ve bir alıcı arasında karşılıklı bilgi alışverişi anlamına gelir. Berke VARDAR’a göre iletişim "konuşucuyla dinleyici arasında bilgi alş̧erişi; karşılıklı bilgi aktarımı"(2002:43) biçiminde tanımlanır. Bu duygu, düşünce ya da bilgilerin aktarımı işaretler, mimikler, konuşma ya da yazı aracılığıyla yapılabilmektedir. İletişimin genel olarak sözlü, sözsüz ve yazılı olmak üzere üç türü olduğu söylenebilir. Çalışmanın konusuna bağlı olarak burada sadece yazılı iletişim ele alınmıştır.

\section{Yazılı iletişim}

Milattan önce yaklaşık 300o'li yıllarda yazının bulunması iletişime yeni bir boyut kazandırmış ve iletişimin yazılı olarak yapılabilmesine olanak sağlamıştır. Tarih kaynaklarına göre ilk yazıların Sümerler tarafından yumuşak kil üzerine yazıldığı bilinmektedir. Bu da bir bakıma yazılı iletişimin başlangıcını simgeler. Yazılı iletişim, insanlar arasındaki her türlü duygu, düşünce ve bilgi paylaşımının yazı araçlarıyla sağlanmasını ifade eder. Teknolojinin gelişimiyle birlikte günümüzde artık yazılı iletişimde posta, telgraf, telefon, televizyon, bilgisayar gibi çok çeşitli yazışma araçlarından bahsetmek mümkündür. Gönderici alıcıya iletisini ulaştırmak için bu araçlardan kendisine ve alıcıya en uygun olduğunu düşündüğü yöntemi tercih eder ve bu yolla iletisini göndermeyi hedefler. İletişimin yazılı olarak yapılması duruma göre bir gereklilik ya da bir tercih olabilir. Örneğin, herhangi bir kurum ya da kuruluşa resmi bir başvuru söz konusu olduğunda bu başvurunun çoğu durumda yazılı olarak yapılması gerekir. Bu durumda yazılı iletişimin bir gereklilik olduğu görülmektedir. Bununla birlikte, bazen sözlü iletişim yerine yazılı iletişimin tercih edildiği durumlar da olabilir. Örneğin bir kimse herhangi bir konuda bir bilgilendirme ya da açıklama yapacağı zaman yazılı dilin sözlü dile göre daha etkili olabileceği düşüncesiyle yazılı iletişim seçeneğini kullanabilir. Bu durumda yazılı iletişim bireysel bir tercih niteliği taşır. "Yazıl iletişimin tercih edilmesinin en büyük nedeni kantlanabilir ve de somut olmasıdır" (Benzer, 2018: 129). Yazılı iletişimde en önemli unsurlardan biri iletişimin içeriğini oluşturan metinlerdir. Yazışmada kullanılan metinler iletişim türüne göre birtakım ayırt edici özellikler taşır. Aşağıda yazışma metinlerinin genel özelliklerine kısaca değinilmiştir.

\section{Yazışma metinleri}

Yazışma metinleri yazılı iletişimde kullanılan metinleri ifade eder. Yazışma metinleri kendine özgü birtakım özelliklere sahiptir ve bu yönüyle sözsüz ve sözlü iletişim türlerinden farklıdır. Bunların başında yazılı iletişim metinlerinin kontrol edilebilme özelliği gelir. Zira yazılı iletişimde metin alıcıya gönderilmeden önce değiştirilebilir ve düzeltilebilir. Bilindiği gibi, "ağızdan çıkan söz yaydan çıkan ok gibidir, gittiği yerden dönmez” şeklinde bir atasözü vardır. Sözlü iletişim esnasında söylenen bir tümcenin ya da bir ifadenin düzeltilebilmesi oldukça zordur. Buna karşın, yazılı iletişimde metnin alıcıya 
iletilmeden önce tekrar gözden geçirilmesi ve gerektiğinde birtakım ekleme ve çıkarmalar yapılarak değiştirilmesi mümkündür. Özellikle resmi niteliğe sahip olan yazışma metinleri için bu durum daha da önemlidir. Çünkü iletişimdeki amaçlardan biri de doğru anlaşılmaktır. Yazışma metinlerinin alıcıya iletilmeden önce tekrar gözden geçirilmesi iletişimde doğru anlaşılmaya katkı sağlar.

Yazışma metinlerinin bir diğer özelliği bağlayıcı olmasıdır. Latince "Verba volant scripta manent" "yani söz uçar yazı kalı” sözünden de anlaşılacağı gibi, yazılı olarak yapılan iletişim kalıcı özelliğe sahiptir ve bu noktada hem gönderici hem de alıcı bakımından bağlayıcı bir özelliğe sahiptir. Örneğin kişiler ya da kurumlar arasında bir sözleşme olması durumunda taraflar arasındaki anlaşma konuları yazıyla kalıcı hale gelir ve her iki taraf için de sözleşme metninde yer alan maddelere bağlı olmak durumundadır. Yazışma metinlerini bu özelliklerine ek olarak yapı, dil, biçim gibi çeşitli yönlerden de incelemek mümkündür.

\subsection{Yazışma metinlerinin yapısı}

Yazışma metinlerinin diğer birçok metin türünden farklı yapısal özellikleri vardır. Örneğin herhangi bir kurum ya da kuruluşa yönelik resmi bir yazı yazılacağı zaman bu yazıda gönderici, alıcı, iletişim vb. bilgilerin yer aldığı belli bölümlerden oluşan bir metin yapılanması söz konusudur. Ayrıca bu metin yapılanması resmi ve samimi yazışmalarda birbirinden farklılıklar içerir. Buradan hareketle yazışma metinlerinin belli bir planlamaya göre hazırlandığını söylemek mümkündür. Bu planlama da yazılı iletişimi sözlü iletişimden ayıran özelliklerden biridir. Çünkü sözlü iletişimde genel olarak bir metin planı yapmak oldukça zordur. Örneğin bir konuda açıklama yapan bir kişi, konuşma esnasında konuya nasıl başlayacağı, gelişme kısmında nasıl devam edeceği ve tümcelerini nasıl bağlayacağı konusunda bir planlama yapmakta zorlanabilir ya da önceden yapmış olduğu hazırlık varsa buna göre konuşmasını sürdürmesi her zaman kolay olmayabilir. Ancak yazılı bir açılama söz konusu olduğunda, açıklama metni belli bir plana göre oluşturulur ve bu bakımdan sözlü iletişime göre daha etkilidir.

\subsection{Yazışma metinlerinde dil}

Yazılı iletişimde tam olarak anlaşılmayı sağlayabilmek amacıyla yazışma metinlerinde sade ve anlaşılır bir dil kullanılması önemlidir. "En iyi anlaşılma biçimi tümceleri mümkün olduğunca kısa tutmaktır" (Maury, 1986: 23). Zira metni daha gösterişli ve süslü kılma kaygısıyla özellikle resmi nitelikteki bir yazışma metninde ağdalı bir dil kullanmak verilmek istenen mesajın tam olarak aktarılmasına engel olabilir. Çünkü böyle yaparak aslında metni daha karmaşı bir biçime sokmak anlaşılabilirliği düşürecektir ve yazılı iletişimde hedeflenen etkinin oluşma ihtimali de azalacaktır. Bununla birlikte, özellikle samimi nitelikteki yazışmalar yazınsal türe de girdiğinden, bu metinlerde yazınsal türün özelliklerine yer verilebilmektedir. Örneğin bir aşk mektubu günümüzde çok yaygın olmasa da yapı itibariyle yazışma metnine, içerik olarak da yazınsal türe örnektir. Bu nedenle, böyle bir mektupta sade bir dil kullanımı bu mektupla hedeflenen etkiyi tam olarak yaratmayacaktır. Hatta ters tepkiye bile neden olabilir. Bu yüzden, yazışma metinlerindeki dil kullanımının resmi ve samimi yazışmalara göre farklı olabileceğini belirtmek yararlı olacaktır.

Yazışma metinlerinde ayrıca etkileyici bir dil kullanmak gerekir. Sözlü iletişimde kullanılan ve sözün etkisine katkı sağlayan jest, mimik, ses tonu gibi unsurlar yazışma metinlerinde olmadı̆̆ından, yazışmalarda etkili bir dilin kullanılmasına özen gösterilmelidir. Sözcük seçiminin iyi yapılması da oldukça önemlidir. Hem resmi hem de samimi yazışma metinlerinde içeriğe uygun bir dil kullanımına ve nezaket ifadelerine çok dikkat edilmesi gerekir. Çünkü bu türlerden her birinin kendine özgü bir dili 
söz konusudur. Örneğin, resmi bir yazışmada "sen” yerine "siz" kullanmak gerekir. Yine metnin sonuna eklenecek olan kapanış ifadeleri de resmi ve samimi yazışmalarda farklıdır. Buna örnek olarak Türkçede samimi bir yazışmanın sonunda "hoşçakal, görüşürüz..." gibi ifadeler kullanılabilirken, resmi yazışmanın sonunda "saygılarımla" ifadesinin kullanılması gerekir.

Yazılı iletişim metinlerinin dilbilgisel kurallara uygun bir biçimde oluşturulması metnin işlevi açısından önemlidir. Sözlü iletişim sırasında yapılan dil yanlışları çok fazla belirgin olmayabilir. Örneğin, tümce düşüklüğü, anlatım bozukluğu ya da yanlış sözcük kullanımı sözlü dilde çok dikkat çekmeyebilir ancak bunlar yazılı dilde daha çok öne çıkar ve alıcının dikkatini daha çok çeker. Hatta bazen tümceler bu yanlışlıklardan dolayı tam anlaşılamayabilir ve dolayısıyla yazışma metniyle hedeflenen etki elde edilemez.

Bunların dışında, yazışma metni yazarken tekrara düşmemeye de dikkat edilmelidir. Aynı anlama gelecek tümcelerin metnin farklı bölümlerinde farklı biçimlerde verilmesiyle tekrara düşülebilir. Ya da eşanlamlı sözcüklerle böyle bir durum söz konusu olabilir. Bu da alıcının dikkatini çeker ve iletişimi olumsuz anlamda etkileyebilir.

\subsection{Yazışma metinlerinde biçim}

Yazışma metinlerinin biçimi metnin türüne göre farklılık gösterebilir. Örneğin iş başvurusuna yönelik bir özgeçmiş genel olarak en fazla bir sayfadan oluşur. Resmi bir kuruma yazllacak olan bir dilekçenin ise daha kısa olması beklenir. Bilgisayarda resmi bir yazışma metni oluşturulacağı zaman genellikle tercih edilen bir sayfa biçimlendirmesi söz konusudur. Metinde yazı karakteri ve puntosu olarak belli seçenekler tercih edilmektedir. Örneğin yazı karakteri olarak "times new roman" ya da "arial”, yazı puntosu olarak da 11 ya da 12 punto sı tercih edilen özelliklerdendir. Metnin genel yapısı iki yana yash olarak düzenlenir. Elle yazılıyorsa, yine aynı şekilde estetik açıdan hizalama, satır araları, kenar boşlukları, satır başı, yazım kuralları gibi konulara önem verilmelidir.

Yazışma metinlerinin yukarıda sayılan özellikleri birçok dilde benzerlik gösterir. Bununla birlikte, yazışma metinlerinde dillere göre farklılık içeren bazı durumlar da söz konusudur. Aşağıda Türkçe ve Fransızcadaki yazışma metinleri biçim ve çeviri yönünden karşılaştırmalı olarak incelenmiştir.

\section{Türkçe ve Fransızca yazışma metinlerinin incelenmesi}

Daha önce de ifade edildiği gibi, yazılı iletişimde çok çeşitli araçlar ve yöntemler geliştirilmiştir. Tüm bu yöntemlerin her biri ayrı bir incelemenin konusunu oluşturur. Bu nedenle bu çalışmada yazışma yöntemlerinden sadece mektup ve e-posta örneklerinin hem resmi hem de samimi düzeyde türleri değerlendirilmiştir. Bu bölümde önce Türkçe ve Fransızca mektup ve e-posta metinlerine resmi ve samimi türlerin her birine birer örnek verilecek ve bu örnekler üzerinden biçimsel karşılaştırma yapılacak, daha sonra bu örneklerden hareketle yazışma metinlerinin çevirisi konusunda değerlendirmeler yapılacaktır.

\subsection{Mektup}

Mektup genel olarak, haberleşme amacıyla ve çoğunlukla posta yoluyla herhangi bir kimseye ya da kuruma gönderilen yazılı kağıt şeklinde tanımlanır. Resmi ve samimi içerikli olmak üzere genel anlamda iki tür mektup olduğu söylenebilir. İçerik olarak dilekçe, başvuru ya da bilgi talebi gibi konularda yazılan mektuplar resmi mektuplara örnektir. Kartpostal, aşk mektupları, asker ya da hükümlü mektupları da 
samimi mektuplar arasında sayılabilir. Türkçede ve Fransızcada resmi ve samimi mektuplar büyük oranda benzerlik taşısa da bazı noktalarda birbirinden farklılıklar içerir. Aşağıda her iki dilde de önce resmi ardından samimi mektup biçimleri incelenmiştir.

\subsubsection{Resmi mektup}

Resmi mektuplar idari, ticari, hukuki, diplomatik gibi çok çeşitli alanlarda kullanılmaktadır. Resmi mektupları bireysel ve kurumsal kapsam açısından ikiye ayırmak mümkündür. Bireysel anlamdaki resmi mektuplar herhangi bir kimsenin bir kurum ya da kuruluşa yazmış olduğu başvuru, dilekçe, bilgi talebi gibi konuları içeren mektupları oluşturur. Kurumsal düzeydeki mektuplar ise daha çok resmi yazı olarak nitelendirilen ve kurumsal düzeyde kullanılan mektuplardır. Resmi mektup metinlerinde resmi bir dil kullanımı söz konusudur. Aşağıda Türkçe ve Fransızca resmi mektup örnekleri yer almaktadır.

\section{Türkçe resmi mektup örneği:}

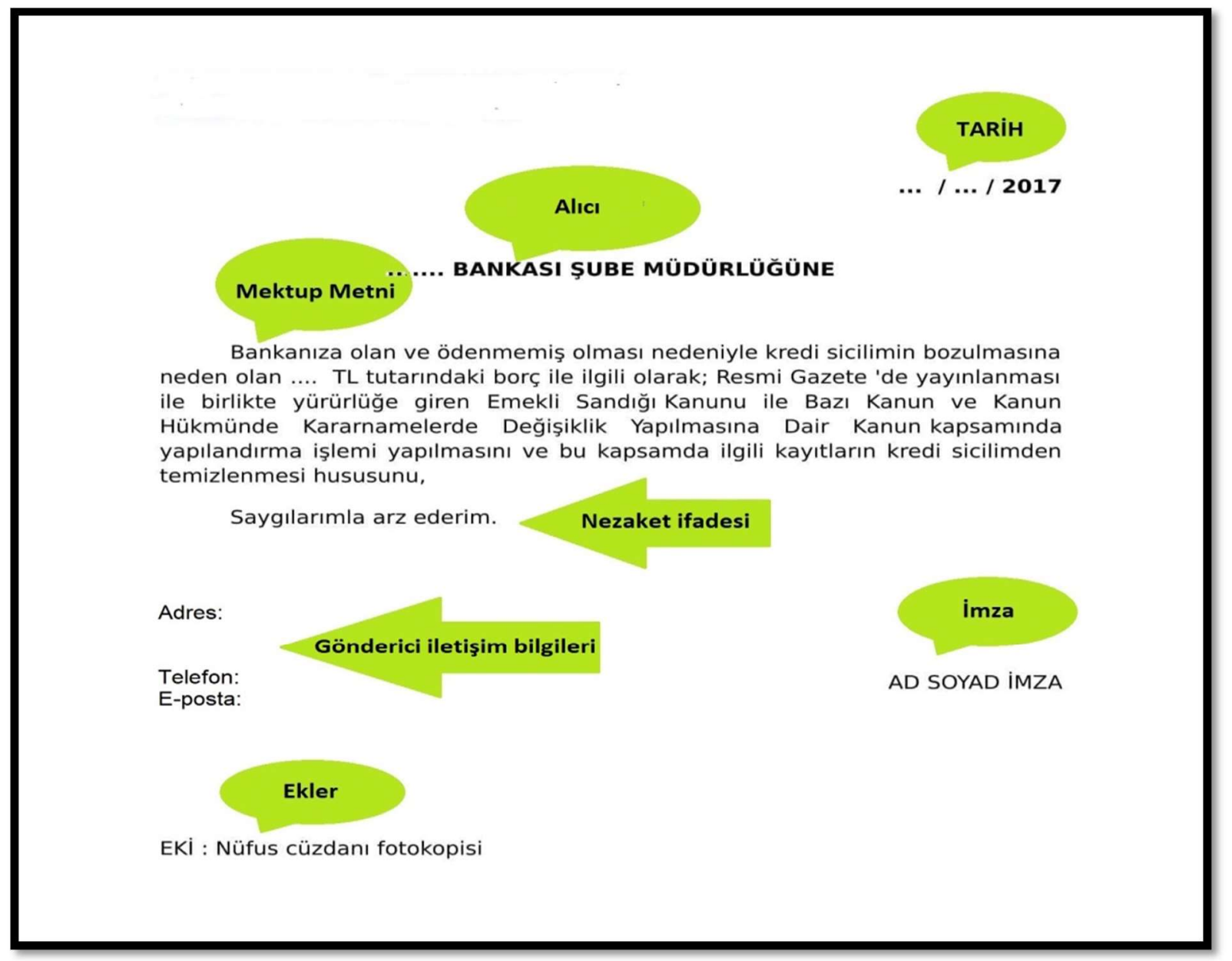

Şekil 1. Türkçe resmi mektup örneği (Dilekçe örneği, 2019) 


\section{Fransızca resmi mektup örneği}

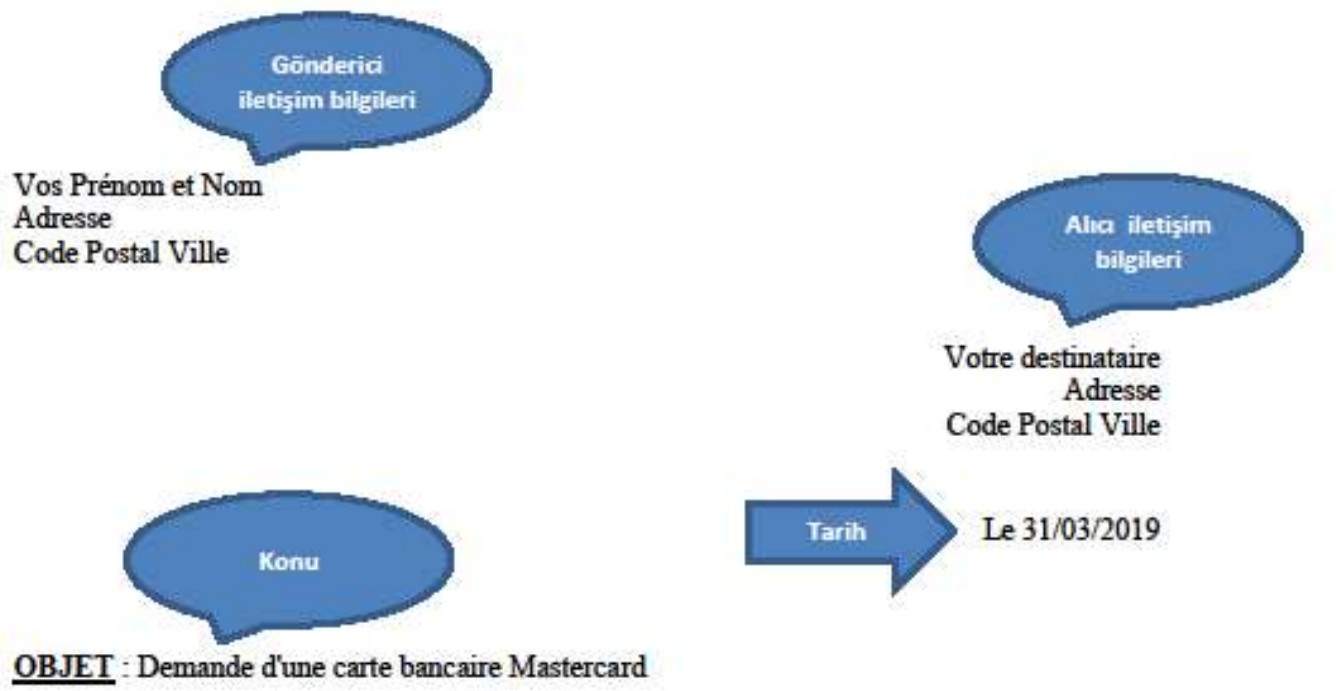

Madame, Monsieur, Hitap ifadesi

Titulaire d'un compte courant dans votre agence sous le numéro XXXXXX, je désire obtenir une nouvelle carte bancaire de type Mastercard.

Merci de me contacter en vue d'un rendez-vous et m'indiquer les documents nécessaires à foumir pour l'obtention de cette carte.

Dans l'attente de votre réponse, je vous prie de croire, Madame, Monsieur, à l'assurance de ma parfaite considération.

Signature

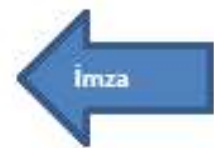

Şekil 2. Fransızca resmi mektup örneği (Lettre de demande, 2019)

Örnekler incelendiğinde, Türkçede olduğu gibi Fransızcada da resmi mektup biçimlerinin bazı yönlerden benzerlik taşıdı̆̆ görülmektedir. Örneğin, her iki dilde de resmi bir dil kullanılır. Bununla birlikte, biçimsel olarak ve içerik bakımından Türkçedeki resmi mektupla Fransızcadaki resmi mektup arasında bazı farklılıklar olduğu gözlemlenmektedir. Örneğin, Fransızcada mektubun üst kısmında gönderici ve alıcı iletişim bilgilerine yer verilir. Oysa Türkçe resmi bir mektupta alıcıyla ilgili iletişim bilgileri çoğunlukla yer almaz. Türkçe resmi yazışmada gönderici iletişim bilgilerinin yeri ise Fransızcadakinden farklıdır. Türkçe ve Fransızca resmi mektuplar arasındaki benzerlikler ve farklılıklar aşă̆ıdaki çizelgede özetlenebilir: 


\begin{tabular}{|l|l|l|}
\hline \multicolumn{2}{|c|}{ Resmi mektup } \\
\hline & Türkçe & Fransızca \\
\hline Alıcı bilgileri & - & $\begin{array}{l}\text { En üstte solda } \\
\text { Alıc iletişim bilgileri }\end{array}$ \\
\hline Gönderici bilgileri & $\begin{array}{l}\text { Metin gövdesinin altında solda } \\
\text { İetişim bilgileri }\end{array}$ & $\begin{array}{l}\text { Alıcı bilgilerinin altında sağda } \\
\text { Gönderici iletişim bilgileri }\end{array}$ \\
\hline Konu & Gerekliyse yazılır & Gerekliyse yazılır \\
\hline Referans & Gerekliyse yazılır & Gerekliyse yazılır \\
\hline Hitap & Kuruma yönelik & Madame, Monsieur, \\
\hline Nezaket ifadesi & Saygılarımla & Je vous prie d'agréer... \\
\hline İmza & $\begin{array}{l}\text { Metnin sağ altında } \\
\text { İmza ve ad-soyad }\end{array}$ & $\begin{array}{l}\text { Metnin sağ/sol altında } \\
\text { İmza/ad-soyad }\end{array}$ \\
\hline Ekler & $\begin{array}{l}\text { Sayfanın alt kısmına } \\
\text { dosya adları eklenir }\end{array}$ & $\begin{array}{l}\text { Sayfanın üst kısmına } \\
\text { dosya adları eklenir }\end{array}$ \\
\hline
\end{tabular}

Çizelge 1. Türkçe ve Fransızca resmi mektupların karşılaştırması

\subsubsection{Samimi mektup}

Samimi içerikli mektuplar eş, aile, arkadaş, dost ve yakın çevredeki tanınan kişilere yönelik olarak yazılan mektupları kapsar. Bu nedenle samimi mektubun biçim ve içeriği resmi mektuptan bazı noktalarda farklılık gösterir. Örneğin samimi mektupta seslenme ifadelerinde samimi bir dil kullanılır. Bu tür mektuplarda, içerik olarak gündelik dil kullanımı ağırlıklı olarak tercih edilir. Aşağıda Türkçe ve Fransızca samimi mektuplara örnekler verilmiştir:

\section{Türkçe samimi mektup örneği}

Sevgili arķadaşım,

Bu dünyada en sevdiğim değerlerimden biri olduğunu sen de biliyorsun. Sen benim ailemden biri gibisin. Sen benim çocukluğumsun. Seninle oynadiğımız oyunları, acı tat li günlerimizi, tatlı kavgalarımızı, hemen sonrasında dayanamayı barışmak, için göstermiş olduğumuz çabalan hayatım boyunca unutamam. Ne zaman bir şeye canım sıkılsa, hemen seni yanımda bulabileceğimi bilirim. Senin de bunu biliyor olman bana huzur veriyor. Insanm senin gibi bir arkadaşımm olmast, $6 u$ dünyada sahip olunabilecek birçok güzellikten daha güzel. Seninle daha çok güzel günler yaşayacak, birçok paylaşımda 6ulunacağız. Ve bu süreçte hem yan yana, omuz omuza olacağız. Benim en yaß̧ın

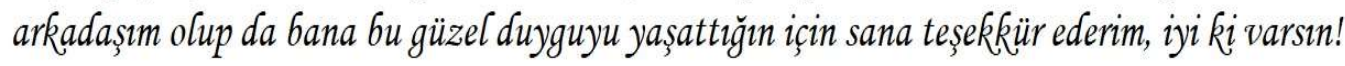

Şekil 3. Türkçe samimi mektup örneği (En yakın arkadaşa mektup örneği, 2019) 


\section{Fransızca samimi mektup örneği}

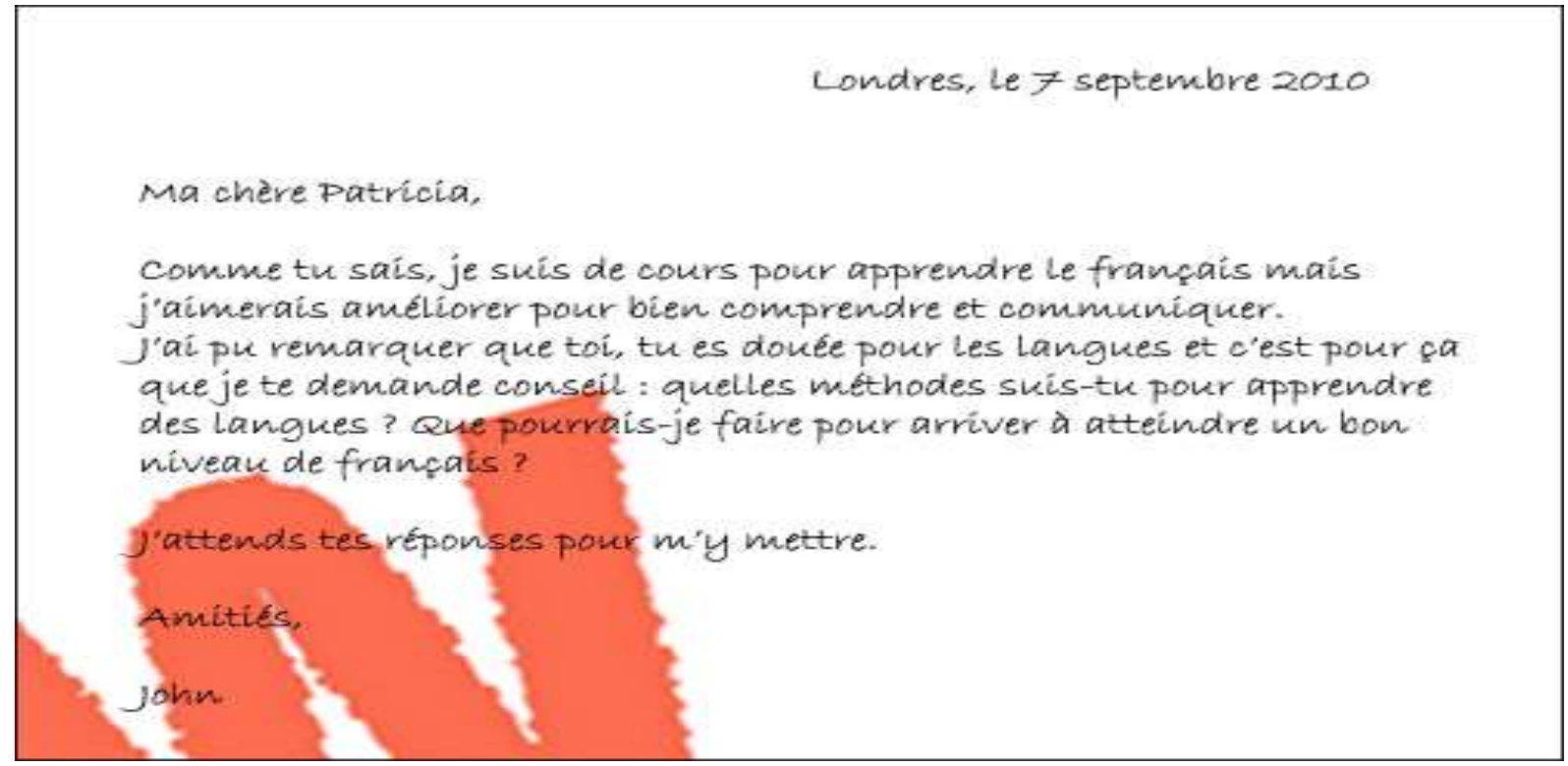

Şekil 4. Fransızca samimi mektup örneği (Rédiger une lettre amicale, 2019)

Yukarıda verilen Türkçe ve Fransızca örneklerden hareketle, iki dildeki samimi mektuplar aşağıdaki çizelgede şöyle özetlenebilir:

\begin{tabular}{|l|l|l|}
\hline \multicolumn{2}{|c|}{ Türkçe ve Fransızca samimi mektupların karşılaştırması } \\
\hline & Türkçe & Fransızca \\
\hline $\begin{array}{l}\text { Alıcı bilgileri } \\
\text { (Seslenme) }\end{array}$ & $\begin{array}{l}\text { Ad-soyad } \\
\text { Seslenme ifadesi ve Ad } \\
\text { Seslenme ifadesi }\end{array}$ & $\begin{array}{l}\text { Ad-soyad } \\
\text { Seslenme ifadesi ve Ad } \\
\text { Seslenme ifadesi }\end{array}$ \\
\hline $\begin{array}{l}\text { Gönderici } \\
\text { bilgileri }\end{array}$ & Sayfanın sonunda & Sayfanın sonunda \\
\hline Nezaket ifadesi & Samimi ifadeler & Samimi ifadeler \\
\hline İmza & $\begin{array}{l}\text { Ad } \\
\text { Ad-soyad }\end{array}$ & $\begin{array}{l}\text { Ad } \\
\text { Ad-soyad }\end{array}$ \\
\hline
\end{tabular}

Çizelge 2. Türkçe ve Fransızca samimi mektupların karşılaştırması

Örneklerde de görüldüğü gibi, Fransızca samimi mektup biçimi Türkçedekiyle hemen hemen her yönden benzerlik taşır. Her iki dilde yazılan samimi mektupta da "sen" dili kullanılır ve metin samimi içeriklidir. Biçim olarak da Türkçe ve Fransızca samimi mektupların aynı yapıya sahip olduğunu söyleyebiliriz.

Samimi nitelikteki mektuplar daha çok iletişim teknolojilerinin fazla gelişmediği ve yaygın olmadığı dönemlerde kullanılan mektuplardır. İletişimde teknolojinin gelişimi bu konuda değişiklikleri de beraberinde getirmiştir. Çoğu toplumda artık samimi içerik taşıyan mektupların neredeyse yok olmaya yüz tuttuğunu söylemek mümkündür. Bunun yerine artık elektronik posta ya da kısaca e-posta olarak bilinen yöntem yaygın hale gelmiştir. 


\subsection{E-posta}

Teknolojinin gelişmesiyle birlikte, artık mektubun yerini büyük oranda e-posta almış durumdadır. Hem bireyler hem de kurumlar arasında e-posta kullanımı giderek artmıştır ve günümüzde birçok kurumda yazışmalar e-posta yoluyla yapılmaktadır. Buna bağlı olarak kurumlar çalışanlarına kurumsal e-posta hizmeti sağlamakta ve böylelikle bu durum daha da yaygın hale gelmektedir. Ayrıca bireyler arasında eposta kullanımı da oldukça yaygındır. Akıllı telefon olarak ifade edilen yeni kuşak telefonlar sayesinde e-postalara eskiye göre çok daha hızlı bir biçimde erişmek mümkündür. Bu da bir bakıma e-posta kullanımının kapsamının genişlemesine katkı sağlamaktadır. E-posta aracı hem resmi hem de samimi yazışmalarda sıkça tercih edilen bir iletişim aracı olarak kabul edilmektedir. Türkçede ve Fransızcada eposta metinleri dil ve biçim yönünden benzerlikler içermektedir. E-posta metinlerini de resmi ve samimi olmak üzere iki başlık altında ele almak mümkündür.

\subsubsection{Resmi e-posta}

Resmi e-postalar ticari, hukuki, siyasi, diplomatik vb. birçok alanda resmi amaçlı olarak yazılan epostalardan oluşur. Örneğin, özel ya da resmi herhangi bir kurumda çalışanlar ile kurum idaresi arasında yapılan e-posta yazışmaları resmi niteliktedir. Resmi mektuptaki dil ve biçimsel yapıyla ilgili birçok yazışma kuralı resmi e-posta için de geçerlidir. Aşağıda Türkçe ve Fransızca dillerinde resmi eposta için birer örnek verilmiştir.

\section{Türkçe resmi e-posta örneği}

\begin{tabular}{||l||}
\hline Kime: $\mathbf{x x x @ x x x . c o m}$ \\
\hline Konu: Makaleniz alındı. \\
\hline Sayın Prof. Dr. ........, \\
Değerlendirilmek üzere "xxxxxxxxxxxxxx" başlıklı makaleniz alındı ve bir editör atandı. Makale \\
durumunuzu www........com adresinden takip edebilirsiniz. \\
Çalışmanızı bize gönderdiğiniz için teşekkür ederiz. \\
Saygllarımızla. \\
............... Yayın Sistemi \\
…........... Dergisi
\end{tabular}

Şekil 5. Türkçe resmi e-posta örneği

Yukarıda bir akademik hakemli derginin yazara gönderdiği bir e-posta örneği görülmektedir. Bu örnekte gönderici alıcıya yanıt vermektedir. Seslenme biçimi olarak Türkçede resmi seslenme ifadelerinden biri olan "sayın" ifadesi kullanılmıştır. Yine metnin sonunda bitiş ifadesi olarak saygı belirten sözcü̆üun kullanıldığı görülmektedir. 


\section{Fransızca resmi e-posta örneği}

\section{À : xxx@xxx.com}

Objet : demande d'informations concernant l'appartement rue de la république

Monsieur Durand,

Je suis étudiant et je suis à la recherche d'un appartement car je viens d'arriver à Lyon. Suite à votre annonce parue sur le site .....fr, je me permets de vous écrire pour avoir des informations complémentaires sur cet appartement. Dans votre annonce, vous mentionnez la superficie totale de l'appartement. Pourriez-vous m'indiquer précisément la superficie du salon et de la chambre? Comme je suis étudiant, pourriez- vous m'indiquer les justificatifs dont j'aurai besoin pour louer cet appartement?

Je vous remercie d'avance,

Respectueusement,

Andrew Watson 1508

Gervais St. Columbia,

SC 292103221142634

Şekil 6. Fransızca resmi e-posta örneği

Yukarıda bir öğrencinin daire kiralamak üzere bir internet sitesine yazmış olduğu e-posta örneği verilmiştir. Bu örnekte seslenme ifadesi olarak Fransızca saygi içeren bir sözcük kullanılmıştır. Yukarıda verilen Türkçe ve Fransızca resmi e-posta örneklerinden hareketle aşağıda her iki dildeki resmi mektupların biçimsel ve içerik olarak karşılaştırılması yapılmıştır.

\begin{tabular}{|l|l|l|}
\hline \multicolumn{2}{|c|}{ Türkçe ve Fransızca resmi e-posta örneklerinin karşılaştırılması Resmi e-posta } \\
\hline & Türkçe & Fransızca \\
\hline Konu & Gerekli & Gerekli \\
\hline Hitap & Sayın & Madame, Monsieur \\
\hline Nezaket ifadesi & Saygılarımla, & Respectueusement, \\
\hline İmza & $\begin{array}{l}\text { Ad-soyad } \\
\text { İletişim bilgileri }\end{array}$ & $\begin{array}{l}\text { Ad-soyad } \\
\text { İletişim bilgileri }\end{array}$ \\
\hline Ekler & Varsa eklenir & Varsa eklenir \\
\hline
\end{tabular}

Çizelge 3. Türkçe ve Fransızca resmi e-posta örneklerinin karşılaştırılması

Örnekler ve çizelge incelendiğinde, resmi nitelik taşıyan e-postaların Türkçede ve Fransızcada biçimsel ve içerik olarak benzer bir yapıya sahip olduğu görülmektedir. Resmi seslenme ve nezaket ifadeleri her iki dilde yazllan e-posta örneklerinde de kullanılmaktadır. Mektupta olduğu gibi, e-posta metninin sonunda da kapanış bildiren nezaket ifadeleri kullanılmaktadır. Ancak Fransızcada resmi mektupta kullanılan kapanıştaki nezaket ifadeleri resmi e-postada kullanılmaz. Bunun yerine, örnekte de görüldüğü gibi saygı belirten daha kısa ifadeler tercih edilir.

\subsubsection{Samimi e-posta}

Arkadaş, aile, eş, dost, sevgili, yakın çevre vb. kişiler arasında yazılan e-postalar samimi e-postaya örnektir. Her iki dilde yazılan samimi e-postalarda da samimi dil kullanımı söz konusudur ve "sen" dili 
tercih edilir. Samimi mektuplarda olduğu gibi, samimi e-posta metinlerinde de daha çok gündelik dilde yazılmış olan tümceler ağırlıklıdır. Kullanım sıklığı açısından bakıldığında, samimi e-postanın mektuba göre daha yaygın olarak tercih edildiği gözlemlenmektedir. Zira daha önce de belirtildiği gibi, iletişim alanındaki teknolojinin gelişmesiyle birlikte, artık bu tür yazışmalarda mektup yerine e-posta daha çok kullanılmaktadır. Aşağıda Türkçe ve Fransızca samimi e-posta örneklerine yer verilmiştir.

\section{Türkçe samimi e-posta örneği}

\section{Kime: $\mathbf{x x x @ x x x . c o m ~}$}

\section{Konu:}

Tanselciğim merhaba

Geçen gün önerdiğin kebapçıya gittim. Kebabın eti oldukça lezizdi. Salata konusunda da fena değiller. Devamlı gittiğin yer olduğu için burayı senin önerdiğini söyledim garsonlara. “O cimri herif mi?” bakışı attılar. Buradan hiç bahşiş vermediğin çıkarımını yaptım. Yoksa cebinde akrep mi var Tanselciğim?

Gözlerinden öperim.

Selamlar.

Şekil 7. Türkçe samimi e-posta örneği (E-mail nasıl yazılır, 2019).

\section{Fransızca samimi e-posta örneği}

À : xxx@xxx.com

Objet : question de français

Salut Bruno,

Ça va ? Je voulais te demander : comment s'appelle ce petit objet qu'on branche à son ordinateur pour avoir plus d'espace de mémoire?

Merci,

À bientôt,

Gemma

Şekil 8. Fransızca samimi e-posta örneği (Savoir-faire en français, 2019)

Yukarıda verilen örneklerden hareketle, Türkçe ve Fransızca samimi içerikli e-posta metinlerinin karşılaştırmasını aşağıdaki çizelgede veriyoruz. 


\begin{tabular}{|c|c|c|}
\hline \multicolumn{3}{|c|}{ Türkçe ve Fransızca Samimi e-posta } \\
\hline & Türkçe & Fransizea \\
\hline Konu & Gerekli & Gerekli \\
\hline Hitap & $\begin{array}{l}\text { Sevgili ... } \\
\text { Değerli... }\end{array}$ & $\begin{array}{l}\text { Cher..., Chère.... } \\
\text { Mon cher..., ma chère... }\end{array}$ \\
\hline Nezaket ifadesi & Samimi bir dil & Samimi bir dil \\
\hline İmza & $\begin{array}{l}\text { Ad } \\
-\end{array}$ & $\begin{array}{l}\text { Ad } \\
\text { Soyad }\end{array}$ \\
\hline Ekler & Varsa eklenir & Varsa eklenir \\
\hline
\end{tabular}

Çizelge 4. Türkçe ve Fransızca samimi e-posta örneklerinin karşılaştırılması

Örneklerde ve çizelgede görüldüğü gibi, Türkçede ve Fransızca samimi e-posta metinlerinin arasında büyük oranda benzerlik söz konusudur. Bunun internet kullanımına bağlı olarak diller arasındaki iletişimden ileri geldiği söylenebilir. İletişim teknolojilerinin gelişimi diller arasındaki etkileşime de büyük oranda katkı sağlamakta ve bu süreci daha da hızlandırmaktadır. Buna bağlı olarak, toplumlar arasında her ne kadar diller farklı olsa da yazışma biçimleriyle ilgili birçok konuda benzerlikler ortaya çıkmaktadır. Yazışma metinlerinin yapısı buna bir örnek niteliğindedir.

Yazılı iletişimde mektup kullanımı daha önce de ifade edildiği gibi, teknolojideki gelişmelere bağlı olarak azalmıştır. Özellikle samimi mektup yazışmaları oldukça azalmıştır. Bunun nedenleri arasında internetin yaygınlaşması verilebilir. Zira gelişen teknolojiyle birlikte artık yazılı iletişimde mektup yerini büyük oranda internete bırakmıştır. İnternet sayesinde mektup daha hızlı bir şekilde gönderilebilmektedir. Bununla birlikte, iletişim teknolojilerinin kullanılamadığı durumlarda mektup türünün geçerli olduğu da bir gerçektir. Buna hapishanedeki mahkûmların durumları örnek olarak verilebilir.

Teknolojiye bağlı olarak, yazılı iletişim türlerinde görülen değişiklikler, yazışma metinlerinin gerek yapı gerekse biçim bakımından bazı değişiklikleri de beraberinde getirdiği görülmektedir. Bu tür değişiklikler çoğunlukla metin gövdesinin dışında kalan bölümlerde söz konusudur. Örneğin, mektupta gönderici tarafından yazılan yer ve tarih ifadeleri e-postada otomatik olarak sistem tarafından sağlanmaktadır. Epostada dosya ekleri yine aynı şekilde sistemin içinde ilave bir özellik olarak verilmektedir. Ayrıca, Fransızca resmi mektupta kullanılan ve saygı bildiren uzun kapanış ifadelerinin yerine e-postada daha kısa ifadeler kullanılır.

\section{Yazışma metinlerinin çevirisi}

Birçok metin türünde olduğu gibi, yazışma metinlerinin de bir dilden diğerine aktarılma gereksinimi her zaman söz konusudur. Türkiye'nin Fransa ile ve Fransızcanın konuşulduğu ülkelerle olan ilişkileri dikkate alındığında, gerek bireysel gerekse kurumsal düzeydeki yazışmaların Türkçeden Fransızcaya ya da tersi yönde çevirisine ihtiyaç duyulmaktadır. Yazışma metinlerinin çevirisinde özellikle çevirmen adayları açısından güçlük oluşturabilecek bazı durumlar söz konusu olabilir. Her ne kadar Türkçe ve Fransızcadaki yazışma türleri ve bunlara bağlı olarak yazışma metinleri birçok yönden benzerlik taşısa da, bazı dilsel ve kültürel farklılıklar çevirmen için güçlük içerebilir. Bu bağlamda, yazışma metinlerinin çevirisi konusunu resmi ve samimi olmak üzere iki başlık altında inceleyebiliriz. 


\subsection{Resmi mektup çevirisi}

Resmi yazışma metinlerinin Türkçeden Fransızcaya ya da tersi yönde yapılan çevirisinde ortaya çıkabilecek güçlükler, her iki dilde yer alan bazı ifadelerin farklı olmasına bağlı olabilir. Örneğin, Türkçe resmi yazışma metinlerinde çoğu zaman seslenme ifadeleri yer almaz. Bunun yerine kuruma yönelik bir hitap biçimi söz konusudur. Oysa Fransızcada resmi yazışmalarda metin gövdesine geçilmeden önce mutlaka seslenme ifadeleri yer alır. Ayrıca bu seslenme ifadeleri muhatabın durumuna göre de değişebilir. Alıcının kim olduğunun gönderici tarafından biliniyor ya da bilinmiyor olması durumuna göre seslenme ifadeleri farklıdır. Burada özellikle Fransızcada Türkçeye göre daha çok çeşitte ifade yer aldığı için Fransızcadaki örnek ifadeler üzerinde durulmuştur. Aşağıdaki çizelgede bu durumlara örnekler verilmiştir.

\begin{tabular}{|r|l|}
\hline \multicolumn{2}{|c|}{ Fransızca resmi seslenme ifadeleri } \\
\hline Alıcının tanınmadı̆̆ı durumlar & Alıcinın tanındı̆̆ı durumlar \\
\hline Madame, Monsieur & Cher Monsieur \\
\hline Monsieur & Chère Madame \\
\hline Madame & Chère Mademoiselle \\
\hline
\end{tabular}

Çizelge 5. Fransızca seslenme ifadeleri

Çizelgede de görüldüğü gibi, bu ifadelerin her biri Fransızcada belli bir muhataba yönelik kullanılan ifadedir. Türkçe yazışmalarda bu ve benzeri ifadelerin kullanımı oldukça nadirdir. Fransızca yazışma metinlerinde sıklıkla kullanılan bu tür ifadelerin Türkçeye tam olarak aktarılması güçlükler içerebilir. Örneğin, Fransızcada "madame” sözcüğüne Türkçede "(eskiden) hanımefendi, (şimdi) bayan” (Saraç, 2002: 851) gibi karşllılar verilir. Fransızcadaki "monsieur” sözcüğünün Türkçedeki karşıllkları ise "Bay, Beyefendi, Sayın”dır (Saraç, 2002:915). Türkçe resmi yazışmalarda kişiye yönelik bir seslenme söz konusu olduğunda sadece "sayın" sözcüğü kullanılır. Ancak yukarıdaki çizelgede de görüldüğü gibi, Fransızcada muhatabın erkek ya da kadın oluşuna göre ve daha önceden tanınan bir kimse olup olmamasına göre farklı seslenme biçimleri vardır. Dolayısıyla Fransızca bir yazışma metninde yer alan bu ifadeleri birebir Türkçedeki karşlıklarıyla aktarmak anlaşılabilir bir durum oluşturmayacaktır. Bunun yerine, bu ifadeleri "sayın hanımefendi” ya da sayın beyefendi” biçiminde çevirmek daha doğru olacaktır. Çeviride güçlük oluşturabilecek bir diğer konu da Fransızca metin içinde ve sonunda kullanılan ve nezaket belirten bazı kalıp ifadelerdir. Bunun için aşağıdaki örnekler verilmiştir.

\begin{tabular}{|c|}
\hline Fransizca Talep-rica ifadeleri \\
\hline Auriez-vous l'amabilité de me l'envoyer... \\
Pouvez-vous avoir l'amabilité de me fournir... \\
Je vous serais reconnaissant de bien vouloir réexaminer... \\
Je vous demande donc de bien vouloir rectifier... \\
Je vous prie donc de bien vouloir m'accorder... \\
\hline
\end{tabular}

Çizelge 6. Fransızca talep-rica ifadeleri

Bu çizelgede yer alan Fransızca ifadelerin Türkçeye birebir aktarımı bazı güçlükler içerebilir. Örneğin, Fransızca "Auriez-vous l'amabilité de me l'envoyer..." ifadesindeki "l'amabilité" sözcügü Türkçede "sevimlilik, gönül okşayıcılık, incelik, nezaket..." (Saraç, 2002:66) gibi anlamlara gelmektedir. Buradan hareketle bu ifadeyi Türkçeye bana onu gönderme nezaketine sahip olabilir misiniz” biçiminde çevirmek, Fransızcada tam olarak söylenmek isteneni Türkçeye yansıtmayacaktır. Benzer durum 
çizelgedeki birçok ifadenin çevirisi için geçerli olabilir. Fransızcada talep ya da rica belirten ifadelerden sonra genellikle teşekkür, olumlu yanıt ya da görüşme beklentisinin dile getirildiği ifadeler kullanılır. Türkçe yazışma metinlerinde ise bunlara benzer ifadeler çok sık olmamakla birlikte tercihen kullanılabilmektedir. Bu ifadelere aşağıdaki örnekleri verebiliriz.

Fransızca Teşekkür ve beklenti ifadeleri

Espérant votre accord,

Restant à votre disposition pour éventuel entretien,

J'espère que vous n'y verrez pas d'inconvénient,

Espérant vivement une réponse positive de votre part,

Je reste à votre disposition pour vous fournir des informations complémentaires...

Dans l'attente de votre réponse,

Je vous remercie de bien vouloir considérer...

Vous remerciant de votre compréhension,

Vous remerciant à l'avance de votre intervention,

Dans l'espoir d'une réponse favorable,

Çizelge 7. Fransızca Teşekkür ve beklenti ifadeleri

Fransızca resmi yazışmalarda yukarıdaki çizelgedeki ifadelerin ardından kapanış bölümünü oluşturan nezaket ifadeleri kullanılır ve Türkçeye göre Fransızcada bunun için kullanılan daha fazla türde ifade söz konusudur. Türkçede resmi bir mektubun sonunda genellikle sadece "saygllarımla" ifadesi yeterli olur. Ancak Fransızcada bunu karşılamak için birden fazla farklı ifadenin olduğu görülmektedir. Aşağıda bununla ilgili bazı örneklere yer verilmiştir.

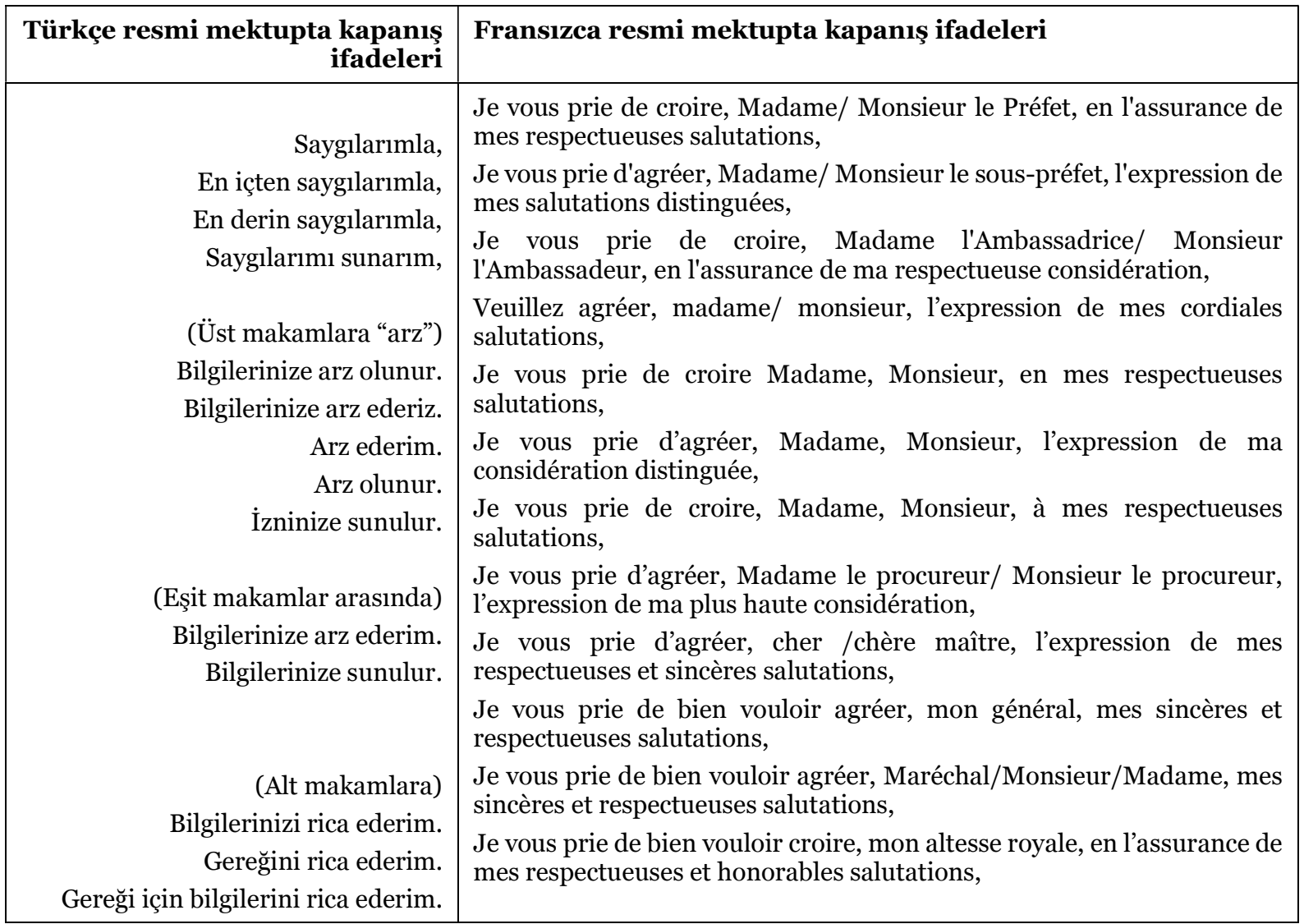


Bilgileriniz rica olunur (İletişim Türleri, 2019).

\begin{abstract}
Je vous prie de bien vouloir agréer, Madame la marquise/ Monsieur le marquis, l'expression de mes honnêtes et respectueuses salutations,

Je vous prie d'agréer, Monsieur/Madame le Secrétaire général de l'Elysée, l'expression de mon profond respect,

Je vous prie d'agréer, Monsieur le Ministre d'Etat, l'expression de ma haute considération,

Avec mes respectueux hommages, je vous prie d'agréer, Madame le Ministre d'Etat, l'expression de ma considération la plus distinguée,

Je vous prie d'agréer, Madame la Conseillère, l'expression de mes respectueux hommages,

Je vous prie d'agréer, très Saint Père, l'expression de mon immense et profonde dévotion,

Je vous prie d'agréer, monseigneur l'évêque, l'expression de ma respectueuse et sincère dévotion,
\end{abstract}

Çizelge 8. Türkçe ve Fransızca resmi mektuplardaki kapanış ifadeleri

Yukarıdaki çizelgede yer alan tümceler Fransızca resmi mektuplarda kapanış bölümünde kullanılan nezaket ifadeleridir. Anlam olarak büyük bir çoğunluğu saygıyı ifade eden bu tümceler için Türkçede az sayıda karşılığın olduğu görülmektedir. Başka bir deyişle, daha önce de ifade edildiği gibi, Türkçe resmi mektupların sonunda "saygılarımla, en içten saygılarımla..." gibi oldukça sade tümceler kullanılır. Dolayısıyla "saygılarımla" ifadesi Türkçeden Fransızcaya aktarılacağı zaman, yukarıdaki çizelgede yer alan ifadelerden bir tanesi yeterli olacaktır. Ancak Fransızcadan Türkçeye çeviri yapılacağı zaman bu ifadelerin çeşitliliğinden dolayı bazı çeviri güçlükleri ve anlamsal bulanıklıklar ortaya çıkabilir. Örneğin, "Je vous prie de croire, Madame/ Monsieur le Préfet, en l'assurance de mes respectueuses salutations » ifadesinde croire Fransizcada "inanmak, güvenmek, sanmak... » (Saraç, 2002 :349) gibi anlamlar taşımaktadır. Bu ifade Türkçeye aktarılırken bu karşılıklardan dolayı yanlış çevirilere yol açabilir. Bu nedenle, Fransızcadaki bu ifadelere Türkçede uygun karşılıkların bulunması daha sağlıklı bir çeviriye olanak sağlayacaktır.

\title{
5.2. Samimi mektup çevirisi
}

Türkçe ve Fransızca samimi mektup türlerinde, özellikle mektubun sonunda verilen kapanış ifadelerinde kültüre bağlı olarak farklı kullanımlar söz konusudur. Çeviriyle ilgili olarak, samimi mektuplardaki kapanış ifadelerinde Türkçe ve Fransızca dillerinde bazı farklllıklar olduğu ve buna bağlı olarak çeviri güçlüklerinin ortaya çıkabileceği söylenebilir. Her iki dildeki samimi mektuplarda sık kullanılan kapanış ifadelerini aşağıdaki çizelgede veriyoruz.

\begin{tabular}{|r|l|}
\hline Türkçe samimi mektupta kapanış ifadeleri & Fransizca samimi mektupta kapanış ifadeleri \\
\hline Selamlar, & Je t'embrasse très tendrement \\
Sevgiler, & Je t'embrasse bien fort \\
Sevgilerimle, & Affectueusement \\
Kendine iyi bak, & Bien à toi \\
Hoşçakal, & A bientôt, \\
Görüşürüz, & A très bientôt, \\
Görüşmek üzere, & Amitiés \\
Bay, & Amicalement, \\
İyi günler, & Bien amicalement, \\
Sağlıcakla kal, & Grosses bises, \\
Sevgiyle kal,, & Bisous, \\
\hline
\end{tabular}




\begin{tabular}{|r|l|}
\hline En iyi dileklerimle, & Cordialement, \\
Öptüm, & Bien cordialement, \\
Sevgi ve muhabbetlerimi sunarım, & Mon meilleur souvenir, \\
Sağllk ve esenlikler dilerim, & Avec toute mon amitié, \\
Selam eder, gözlerinden öperim, & Avec toute mon affection, \\
Kestane kebap acele cevap, & Je t'embrasse bien tristement, \\
Allah'a emanet ol, & \\
\hline
\end{tabular}

Çizelge 9. Türkçe ve Fransızca samimi mektuplardaki kapanış ifadeleri

Türkçe ve Fransızca samimi mektupların bitiş ifadeleriyle ilgili örnekleri artırmak mümkündür. Yukarıdaki çizelgede her iki dilde de en sık kullanılan ifadelere yer verilmiştir. Bu ifadeler Türkçede ve Fransızcada birbirine benzer gibi görünse de bunların söz konusu diller arasında birebir çevirisi çoğunlukla mümkün gibi görünmemektedir. Çünkü bu ifadeler genellikle ait olduğu dilin kültürünü yansıtan ifadelerdir ve birebir çevrilmeye çalışıldığında hedef dilde anlaşılamayabilir. Örneğin, Fransızca "bisous" sözcüğünün Türkçeye birebir çevirisi “öpücükler” benzeri bir şey olacaktır. Oysa bu ifadeyi Türkçeye "öpüyorum" biçiminde çevirmek daha anlaşılır olacaktır. Aynı şekilde, Türkçede çok sık tercih edilen "Allah’a emanet ol, sağlıcakla kal...” gibi kapanış ifadeleri Türkçenin kültürünü yansıtan ifadelerdir ve bu tür ifadeleri Fransızcaya birebir aktarmak çok mümkün görünmemektedir. Dolayısıyla, samimi mektupların sonunda kullanılan bu gibi ifadeleri çevirirken kaynak ve hedef dilin kültürünü dikkate alarak aktarmak daha sağlıklı olacaktır.

Buraya kadar, yazışma metinlerinden mektup türünün Türkçe ve Fransızca dilleri arasındaki çevirilerine yönelik değerlendirmelere yer verilmiştir. Bundan sonraki bölümde ise, yazışma metinleri arasında en sık kullanılan türlerden biri olan e-posta türünün bu iki dil arasındaki çevirilerine yönelik incelemeler üzerinde durulacaktır.

\section{5•3. Resmi e-posta çevirisi}

Resmi e-posta metinlerinin çevirisinde mektup örneklerinde olduğu gibi kapanış ifadelerindeki farklılıklara bağlı olarak güçlükler ortaya çıkabilir. Aşağıda her iki dilde yazılan e-postalardaki kapanış ifadelerine bazı örnekler verilmiştir.

\begin{tabular}{|r|l|}
\hline Türkçe resmi e-postada kapanış ifadeleri & Fransızca resmi e-postada kapanış ifadeleri \\
\hline Sayglarımla, & Cordialement \\
Saygılar sunarım, & Respectueusement \\
En içten saygılarımla, & Sincères salutations \\
En derin sayglarımla, & Bien cordialement \\
Saygı ve selamlarımı sunarım, & Bien sincèrement \\
Arz ederim, & Cordialement vôtre \\
Bilgilerinize, & Sincèrement vôtre \\
Bilgilerinize sunarım, & Bien à vous \\
Rica ederim, & Avec mes salutations \\
& Avec mes remerciements \\
\hline
\end{tabular}

Çizelge 1o. Türkçe ve Fransızca resmi e-postalarda kapanış ifadeleri

Yukarıdaki çizelgede Türkçe bölümündeki "arz ederim” ifadesinin Fransızcaya birebir aktarımı her zaman mümkün olmayabilir. Aynı şekilde Fransızca bölümündeki "cordialement, bien à vous," gibi 
ifadeleri de Türkçeye birebir aktarmak güç görünmektedir. Bu durumda bu ifadelere hedef dildeki en yakın eşdeğer bağlamında tercih edilen kullanım önerilmektedir.

\subsection{Samimi e-posta çevirisi}

Samimi mektup metinlerinde olduğu gibi, samimi e-posta metninin çevirisinde de yine kapanış ifadeleriyle ilgili çeviri güçlükleri söz konusu olabilir. Çünkü bu ifadeler çoğunlukla söz konusu dilin kültürünü yansıtan bir özelliktedir. Başka bir deyişle, samimi yazışmalardaki dil kullanımı o dilin kültürüyle de yakından ilişkilidir. Aşağıda her iki dilde samimi e-postanın sonunda sık kullanılan bazı ifadeler verilmiştir.

\begin{tabular}{|r|l|}
\hline Türkçe samimi e-postada kapanış ifadeleri & Fransızca e-postada kapanış ifadeleri \\
\hline Selamlar, & Bien à toi \\
Sevgiler, & Grosses bises \\
Sevgilerimle, & Bisous \\
Kendine iyi bak, & Je t'embrasse bien fort \\
Hoşçakal, & A bientôt ; \\
Görüşürüz, & Affectueusement ; \\
Görüşmek üzere, & Amicalement, \\
İyi günler, & Amitiés, \\
Sevgiyle kal, & Avec toute mon amitié... \\
En iyi dileklerimle, & Bien cordialement, \\
Öpüyorum, & Mon meilleur souvenir... \\
Öptüm, & \\
\hline
\end{tabular}

Çizelge 11. Türkçe ve Fransızca samimi e-postalarda kapanış ifadeleri

Bunun dışında, samimi dil kullanımına bağlı olarak, kaynak metinde o dile ait kültürel ifadelerin yer alması da ayrıca çeviride güçlük oluşturabilecek durumlar arasında yer alır. Örneğin, yukarıdaki Türkçe samimi e-posta metninde geçen "O cimri herif mi?" ve "Yoksa cebinde akrep mi var" tümceleri Fransızcaya çevrileceği zaman burada özellikle çeviri bölümü öğrencileri açısından zorluklar çıkabilir.

Özetle, ister resmi ister samimi dilde yazılsın, yazışma metinlerinin Türkçeden Fransızcaya ve tersi yönde çevirisinde birtakım güçlüklerin ortaya çıkabileceği görülmektedir. Bu noktada, resmi dilde özellikle Fransızca yazışma metinlerinin Türkçeye göre daha geniş bir yapıya sahip olduğu ve bunun da çeviri açısından bazı zorluklar oluşturabileceği söylenebilir. Samimi yazışma metinlerinde ise, daha çok kültüre bağlı olarak kullanılan ifadelerin çevirisinde güçlükler gözlemlenmektedir.

\section{Sonuç}

Çalışmada Türkçe ve Fransızca yazışma metinlerinin incelemesi yapılmıştır. Ancak yazılı iletişim konusu oldukça geniş bir alanı kapsamaktadır. Bu nedenle çalışmanın sınırlarını daha belirgin tutabilmek adına, yazılı iletişim türlerinden sadece mektup ve e-posta üzerinde durulmuştur. Bu iki türün incelenmesindeki amaçlardan biri, her iki türün de halen birçok alanda kullanılıyor olmasıdır. Bununla birlikte, mektup türünün zamanla gelişen teknolojiye bağlı olarak birçok alanda yerini epostaya bıraktığını da belirtmek gerekir. Bu bağlamda, incelemeyle birlikte, her iki dilde de mektuptan e-postaya geçişte içerik ve yapı bakımından ortaya çıkan değişimler de gözlemlenmiştir. 
Çalışma boyunca yapılan incelemelerde de görüldüğü gibi, Türkçe ve Fransızca resmi yazışma metinlerinde resmi ve seçkin bir dil kullanılmaktadır. Bu durum, resmi nitelikteki yazışma metinlerinin bu iki dilde birbirine yakın özelliklere sahip olduğunu göstermektedir. Bununla birlikte, Türkçe ve Fransızca yazışma metinlerinin her iki dilde de kendine özgü biçimsel bir yapıya sahip olduğunu söyleyebiliriz. Samimi mektuplarda ise, biraz daha serbest bir dil kullanımının tercih edildiği görülmektedir. Bu nedenle, samimi yazışma metinleri resmi yazışma metinleriyle kıyaslandığında daha çok kültürel ifadeler içermektedir. Yazışma metinlerinin çeviri açısından incelenmesi sonucunda, Türkçe ve Fransızca mektup ve e-posta türlerinin gerek dilsel gerekse kültürel açıdan içermiş olduğu farklılıklara bağlı olarak söz konusu metinlerin iki dil arasındaki çeviri sürecinde bazı güçlüklerin oluşabileceği gözlemlenmiştir. Dolayısıyla bu çalışmada, hem Türkçe ve Fransızca yazışma metinlerinin mektup ve e-posta örnekleri üzerinden incelenmesi yapılmış hem de bu tür metinlerin çevirisinde ne gibi güçlükler oluşabileceği konusunda bazı saptamalara yer verilmiştir. Kuşkusuz bu çalışma bu konuyu tüm yönleriyle ele alan çok kapsamlı bir çalışma değildir. Bu konuda yapılması gereken oldukça fazla çalışma söz konusudur. Bu doğrultuda, bu çalışmanın yazışma metinleriyle ilgili bundan sonraki çalışmalara katkı sağlayabilmesi hedeflenmiştir.

\section{Kaynakça}

Benzer, H. (2018). Dil ve İletişim Üzerine, Ankara: Ürün Yayınları.

Dilekçe örneği. (2019, 30 Mart). Erişim adresi https://www.dilekcesepeti.com/wpcontent/uploads/2017/o1/kredi-sicil-aff\%C4\%B1-dilek\%C3\%A7e-\%C3\%B6rne\%C4\%9Fibor\%C3\%A7-bor\%C3\%A7-yap\%C4\%B1land\%C4\%B1racaklar-i\%C3\%A7in-1.jpg (30.03.2019)

Savoir-faire en français: Écrire un courriel amical. (2019, 31 Mart). Erişim adresi https://www.lingoda.com/en/french/learning-material/cefr/A2.2/writing-aninvitation/download.

$\begin{array}{llllll}\text { E-mail nasl } & \text { yazılır. } & \text { (2019, } & 31 & \text { Ekim). } & \text { Erişim }\end{array}$ http://wowturkey.com/forum/viewtopic.php?p=6166655

En yakın arkadaşa mektup örneği. (2019, 31 Ekim). Erişim adresi http://www.eokulegitim.com/enyakin-arkadasa-mektup-ornegi/

Lettre de demande d'une carte bancaire mastercard à son agence. (2019, 30 Mart). Erişim adresi https://www.merci-facteur.com/compte-bancaire/lettre-demande-carte-bancaire-mastercardson-agence-m333.html

İletişim Türleri. (2019, 8 Nisan). Erişim adresi https://docplayer.biz.tr/36959415-Sozlu-iletisimsozsuz-iletisim-yazili-iletisim.html

Kredi sicil affı Dilekçe örneği. (2019, 31 Ekim). Erişim adresi https://www.dilekcesepeti.com/kredisicil-affi-dilekce-ornegi/

Maury, P. (1986). 200 modèles de lettres, Des exemples pour chaque circonstance, Belgique: Marabout, Aller.

Rédiger une lettre amicale. (2019, 30 Mart) Erişim adresi: http://educativa.catedu.es/44700165/aula/archivos/repositorio/3500/3563/html/33_rdiger_une_lett re_amicale.html

Saraç, T. (2002). Büyük Franszzca-Türkçe Sözlük, İstanbul: Adam.

Türkçe Sözlük, (2011). Ankara: Türk Dil Kurumu.

Vardar, B. (2002). Açıklamah Dilbilim Terimleri Sözlüğ̈̈, İstanbul: Multilingual. 